\title{
PENGARUH TERAPI TOKEN TERHADAP KEMAMPUAN MENGONTROL PERILAKU KEKERASAN PADA PASIEN GANGGUAN JIWA
}

\author{
Sunarsih*, Idawati Manurung*, Holidy* \\ *Dosen Jurusan Keperawatan Poltekkes Tanjungkarang \\ Email: sunarsihkarim@gmail.com, idawatimanurung@yahoo.com, holidyilyas@yahoo.co.id
}

\begin{abstract}
Perilaku kekerasan adalah suatu bentuk perilaku yang bertujuan untuk melukai seseorang secara fisik maupun psikologis bisa dilakukan secara verbal, diarahkan pada diri sendiri, orang lain, dan lingkungan. Token Ekonomi adalah suatu wujud modifikasi yang dirancang untuk meningkatkan perilaku yang diinginkan dan pengurangan perilaku yang tidak diinginkan dengan pemakaian token (hadiah-hadiah). Penelitian ini bertujuan untuk mengetahui nilai rata-rata kemampuan mengontrol diri pasien rawat inap di LKS-ODK Kemiling Bandar Lampung sebelum dan setelah dilakukan terapi token. Jenis penelitian ini adalah quasy experimental dengan rancangan pretest-posttest one group design. Jumlah sampel sebanyak 20 orang, dipilih dengan purposive sampling. Instrumen yang digunakan berupa lembar observasi. Hasil yang didapat adalah rata-rata nilai kemampuan mengontrol perilaku kekerasan sebelum dilakukan terapi token adalah 20,05, dan rata-rata nilai kemampuan mengontrol perilaku kekerasan setelah mendapat terapi token adalah 36,20. Hasil uji dependen sample $t$-test didapat bahwa ada pengaruh kemampuan mengontrol perilaku kekerasan sebelum dan setelah dilakukan terapi token ( $\mathrm{p}$ value $0,00<0,05$ ). Diharapkan petugas kesehatan dapat lebih meningkatkan intervensi pada asuhan keperawatan untuk pasien-pasien gangguan jiwa, khususnya perilaku kekerasan dengan menerapkan terapi aktivitas kelompok dan terapi token secara terprogram dan terstruktur.
\end{abstract}

Kata Kunci: Perilaku kekerasan, token ekonomi

\section{LATAR BELAKANG}

Gangguan jiwa menurut American Psychiatric Assosiation dalam Diagnostic and Statistic Manual of Mental (DSM) IVTR (2000 dalam Townsend, 2009) adalah sindroma perilaku yang secara klinik bermakna atau sindroma psikologis atau pola yang dihubungkan dengan kejadian distres pada seseorang atau ketidakmampuan atau peningkatan secara signifikan resiko untuk kematian, sakit, ketidakmampuan atau hilang rasa bebas.

Gangguan jiwa mencapai $13 \%$ dari penyakit secara keseluruhan dan ke kemungkinan akan berkembang menjadi $25 \%$ di tahun 2030, gangguan jiwa juga berhubungan dengan bunuh diri, lebih dari 90\% dari satu juta kasus bunuh diri setiap tahunnya akibat gangguan jiwa (WHO, 2015). Gangguan jiwa ditemukan di semua negara, terjadi pada semua tahap kehidupan, termasuk orang dewasa dan cenderung terjadi peningkatan gangguan jiwa.

Perilaku kekerasan adalah suatu bentuk perilaku yang bertujuan untuk melukai seseorang secara fisik maupun psikologis bisa dilakukan secara verbal, diarahkan pada diri sendiri, orang lain dan lingkungan.

Ketidakmampuan yang terjadi pada klien gangguan jiwa dikaitkan dengan disabilitas akibat gangguan jiwa berat yang dialami. Berdasarkan hasil Riset Kesehatan Dasar Tahun 2013 yang menyebutkan bahwa gangguan jiwa mencapai $1,7 \%$ meningkat dari tahun 2007 sebesar 0,46\%. Wilayah paling banyak dengan kasus gangguan jiwa adalah Daerah Istimewa Yogyakarta, Aceh, Sulawesi Selatan, Bali, dan Jawa Tengah (Kemenkes RI. 2014). Berdasarkan wawancara dengan perawat ruangan pada tanggal 7 Mei 2016, didapatkan data bahwa jumlah pasien rawat inap ada 70 pasien gangguan jiwa dan didapatkan $80 \%$ mempunyai riwayat 
perilaku kekerasan atau sekitar 56 pasien yang memiliki riwayat perilaku kekerasan.

Salah satu terapi yang dapat dilakukan perawat untuk mengontrol perilaku kekerasan adalah dengan diberikan terapi kognitif, terapi keluarga, terapi perilaku : token ekonomi (Susana, 2012). Perilaku ini dipilih peneliti sebagai pendamping terapi psikofarmaka untuk meningkatkan perilaku dalam mengontrol perilaku kekerasan.

Terapi token ekonomi dianggap efektif dalam merubah tingkah laku klien, terapi ini dengan memberikan klien imbalan atas perilaku yang diharapkan dari klien dan mampu dilakukannya. Kegiatan ini dapat dilakukan dengan memberi token (permen, uang, atau makanan) bila klien sukses mengubah perilakunya.

Berdasarkan uraian diatas, maka perilaku kekerasan merupakan gangguan jiwa yang membutuhkan perawatan intensif karena dapat menciderai diri, oranglain dan lingkungan. Salah satu terapi yang dapat digunakan adalah terapi perilaku token ekonomi yang dianggap efektif dalam merubah tingkah laku klien, terapi ini dengan memberikan klien imbalan atas perilaku yang diharapkan dari klien dan mampu dilakukannya.

\section{METODE}

$\begin{array}{clcc}\text { Desain } & \text { yang } & \text { digunakan } & \text { dalam } \\ \text { penelitian } & \text { ini } & \text { adalah } & \text { quasy }\end{array}$ experimentaldengan rancangan pretestposttest one group design. Ciri dari desain penelitian ini dengan memberikan intervensi kepada responden yang akan dilakukan terapi token. Sampel penelitian yang diteliti adalah klien yang dirawat inap dengan perilaku kekerasan dengan memperhatikan kriteria inklusi sebanyak 20 orang dipilih dengan purposive sampling. InstrumenVyang digunakan berupa lembar observasi.

Waktu penelitian dilakukan pada tanggal 20-30 Juli 2016. Tempat penelitian ini dilaksanakan di LKS-ODK Ekspsikotik Kemiling Bandar Lampung.
Variabel independen dalam penelitian ini adalah penelitian ini adalah kemampuan mengontrol perilaku terapi token. Variabel dependen dalam kekerasan. Analisis univariat dilakukan untuk mengetahui kemampuan mengontrol perilaku kekerasan klien menggunakan analisis yaitu mean, median, standar deviasi. Analisa bivariat dilakukan untuk membuktikan hipotesis penelitian menggunakan uji dependen sample t-test.

\section{HASIL}

\section{Analisis Univariat}

Responden dalam penelitian ini berjumlah 20 orang dengan karakteristik usia sebagian besar berusia 31-40 tahun (65\%) dan berusia 19-30 tahun (35\%). Berdasaekan jenis kelamin sebagian besar responden berjenis kelamin laki-laki (70\%). Sedangkan berdasarkan lama rawat responden sebagian besar dirawat dalam kurun waktu 11-25 tahun (60\%).

Tabel 1: Distribusi Responden Berdasarkan Kemampuan Mengontrol Perilaku Kekerasan Sebelum dan Sesudah Terapi Token

\begin{tabular}{lcccc}
\hline \multirow{2}{*}{$\begin{array}{c}\text { Kemampuan mengontrol } \\
\text { perilaku kekerasan }\end{array}$} & \multicolumn{2}{c}{ Pre test } & \multicolumn{2}{c}{ Post test } \\
\cline { 2 - 5 } & $\mathrm{f}$ & $\%$ & $\mathrm{f}$ & $\%$ \\
\hline Tidak mampu mengontrol & 13 & 35 & 6 & 30 \\
\hline Mampu mengontrol & 7 & 65 & 14 & 70 \\
\hline Jumlah & 20 & 100 & 20 & 100 \\
\hline
\end{tabular}

Berdasarkan tabel di atas diketahui bahwa distribusi frekuensi kemampuan dalam mengontrol perilaku kekerasan sebelum dilakukan terapi 7 respondenmampu mengontrl dan setelah dilakukan terapi token kemampuan mengontrol perilaku kekerasan meningkat menjadi 14 responden mampu mengontrol perilaku kekerasan. 
Tabel 2: Distribusi Rata-rata Kemampuan Mengontrol Perilaku Kekerasan Sebelum dan Sesudah Terapi Token

\begin{tabular}{|c|c|c|c|}
\hline $\begin{array}{c}\text { Kemampuan } \\
\text { mengontrol } \\
\text { perilaku kekerasan }\end{array}$ & Mean Median & SD & $\begin{array}{l}\text { Min- } \\
\text { Maks }\end{array}$ \\
\hline $\begin{array}{l}\text { Sebelum dilakukan } \\
\text { erapi token }\end{array}$ & $20,05 \quad 18,00$ & 7,02 & $12-32$ \\
\hline $\begin{array}{l}\text { esudah dilakukan } \\
\text { erapi token }\end{array}$ & $36,20 \quad 39,50$ & 11,23 & $16-50$ \\
\hline
\end{tabular}

Berdasarkan tabel di atas rata-rata skor kemampuan mengontrol perilaku kekerasan sebelum dilakukan terapi token sebesar 20,05 dengan standar deviasi sebesar 7,02. Skor terendah 12 dan teringgi 32. Sedangkan sesudah dilakukan terapi token menjadi sebesar 36,20 dengan standar deviasi sebesar 11,23. Skor terendah 16 dan tertinggi 50.

\section{PEMBAHASAN}

Jika dilihat dari segi usia, berdasarkan hasil penelitian, distribusi frekuensi umur pasien perilaku kekerasan lebih banyak pada kategori usia 31-40 tahun sebanyak 13 orang dengan persentase $65 \%$ dan usia 19-30 tahun sebanyak 7 orang dengan persentase $(35,0 \%)$.Data ini menunjukkan klien yang mengalami perilaku kekerasan lebih banyak pada klien usia produktif. Hal inisejalan dengan konsep Niven (2002) bahwa seseorang yang memiliki usia muda lebih patuh daripada usia tua. Hal ini memungkinkan karena usia muda memiliki kapasitas dan fungsi memori yang lebih baik untuk menerima informasi tentang pengobatan. Struat dan Laraia (2009) menyatakan usia berhubungan dengan pengalaman seseorang dalam menghadapi berbagai macam stresor, kemampuan memanfaatkan sumber dukungan dan keterampilan dalam mekanisme koping. Dapat disimpulkan bahwa usia berhubungan dengan individu dan kemampuan mengambil keputusan dalam menyelesaikan setiap masalah yang datang.
Berdasarkan dari jenis kelamin, didapatkan bahwa distribusi frekuensi jenis kelamin pada pasien perilaku kekerasan lebih banyak pada katagori laki-laki sebanyak 14 dengan persentase $70 \%$. Hal ini menunjukkan bahwa terjadinya perilaku kekeasan lebih banyak dilakukan oleh klien dengan jenis kelamin laki-laki. Hal ini sejalan dengan teori Al-saffar dan Saeed (2007), mengatakan bahwa laki-laki lebih sering di diagnosis sebagai gangguan jiwa dibanding perempuan. Pada umumnya laki-laki dan perempuan mempunyai resiko yang sama untuk menderita gangguan jiwa berat namun, derajat keparahan gangguan jiwa berat lebih besar pada laki-laki. Jenis kelamin mempengaruhi kemampuan mengontrol diri, dikatakan pria lebih temperamental dari pada wanita yang dikatakan lebih sabar dalam mengontrol perilakunya.

Berdasarkan lama dirawat, Berdasarkan hasil penelitian di dapat bahwa distribusi frekuensi lama di rawat pada pasien perilaku kekerasan diketahui lebih banyak pada 11-25 tahun sebesar (60\%). Menurut teori Noviadi (2008) yang dikutip oleh Aristina Haalwa (2014) yang menyatakan bahwa semakin lama pasien dirawat makasemakin banyak pasien tersebut mendapatkan terapi pengobatan dan perawatan. Sehingga dapat disimpulkan bahwa pasien yang sudah lama dirawat maka kemampuan dalam mengontrol perilaku kekerasan dirinya maka semakin baik.

Berdasarkan hasil penelitian dapat diketahui bahwa rata-rata skore kemampuan mengontrol perilaku kekerasan sebelum dilakukan TAK dan terapi token sebesar 20,05 dan rata-rata skore kemampuan mengontrol perilaku kekerasan setelah dilakukan TAK dan terapi token sebesar 36,20. Dari hasil uji paired sample t-test di peroleh $\mathrm{p}$ value $0,00<0,05$, artinya Ho ditolak dan $\mathrm{Ha}$ diterima, ada pengaruh terapi token ekonomi terhadap kemampuan mengontrol perilaku kekerasan pada pasien rawat inap di LKS-ODK Ekspsikotik Kemiling Bandar Lampung Tahun 2016. 
Menurut Parendrawati (2009) bahwa metode pemberian reward atau reinforcementpositif memiliki pengaruh berarti terhadap peningkatan perilaku. Menurut Stuart \& Laraia, (2009) untuk meningkatkan pengetahuan dan perilaku seseorang dapat dilakukan dengan memberikan dasar pengetahuan yang kuat dan pemberian reinforcement positif atau pemberian reward. Strategi lain untuk mengubah perilaku secara efektif adalah dengan token ekonomi. Hasil penelitian yang didapat juga didukung oleh teori Nasir dan Muhith (2011) salah satu terapi perilaku untuk merubah perilaku adalah dengan pemberian token ekonomi yaitu reinforcement positif yang sering digunakan pada klien psikiatri. Terapi perilaku token ekonomi merupakan suatu wujud modifikasi perilaku yang dirancang untuk meningkatkan perilaku yang diinginkan dan pengurangan perilaku yang tidak diinginkan.

Hasil ini sejalan dengan penelitian yang dilakukan oleh Suardika (2012), dengan judul penelitian "Pengaruh Terapi Token Ekonomi terhadap Kemampuan Mengontrol Perilaku Kekerasan Pada Klien Gangguan Jiwa Di Rumah Sakit Jiwa Provinsi Bali". Hasil penelitian ini membuktikan ada perbedaan kemampuan klien mengontrol perilaku kekerasan pre test dengan post test pada kelompok perlakuan sebelum dan sesudah mendapatkan terapi token ( $\mathrm{p}$ value $<0,05$ ).

Terapi token ekonomi dianggap efektif dalam merubah tingkah laku klien, terapi ini dengan memberikan klien imbalan atas perilaku yang diharapkan dari klien dan mampu dilakukannya. Kegiatan ini dapat dilakukan dengan memberi token (permen, uang, atau makanan) bila klien sukses mengubah perilakunya.

Adanya pengaruh terapi perilaku token ekonomi terhadap kemampuan mengontrol perilaku kekerasan disebabkan karena pada saat pelaksanaan terapi perilaku token sebanyak 4 sesi, dimana disetiap sesi ini klien mendapatkan berbagai informasi mengenai kemampuan mengontrol perilaku kekerasan secara fisik, diantaranya klien diajarkan cara menarik nafas dalam dan pukul bantal. Secara verbal, bagaimana cara meminta dengan baik, menolak dengan baik, menerima dengan baik, dan permintaan maaf. Secara spiritual, sholat dan berdoa tanpa harus menyalahkan Tuhan dengan keadaan yang seperti ini. Dan patuh minum obat, apa manfaat patuh minum obat bagi klien, cara minum obat dengan prinsip 5 benar. Informasi yang sudah diberikan ini untuk merubah perilaku klien selain pemberian informasi terapi perilaku token juga diperkuat dengan pemberian reward yang berupa hadiah, yang didapatkan ketika responden mampu menunjukan kemampuan mengontrol perilaku kekerasan. Pemberian token (hadiah) ini dilakukan segera setelah klien mampu mengontrol perilaku kekerasan dan memiliki nilai tertinggi, dengan hadiah yang telah disediakan peneliti, hal ini menyebabkan klien merasa dihargai atas perilaku yang mereka lakukan sehingga klien akan mengulangi perilaku tersebut sehingga terjadi perubahan perilaku yaitu klien menjadi mampu dalam mengontrol perilaku kekerasannya.

Hasil penelitian ini menunjukkan setelah dilakukan terapi perilaku token ekonomi, kepatuhan minum obat pada klien skizofrenia mengalami peningkatan. Terjadinya perubahan perilaku menjadi patuh minum obat setelah diberikan terapi perilaku token ekonomi karena pada saat pelaksanaan terapi perilaku token ekonomi ini klien diarahkan dan diajarkan terlebih dahulu perilaku yang akan dirubah, dan klien akan diberikan reward (reinforcement positif) berbentuk tanda bintang dan tandabintang ini akan ditukarkan dengan hadiah yang sudah disediakan oleh peneliti jika klien mampu merubah perilakunya. Reinforcement positif yang berbentuk tanda bintang ini merupakan salah satu bentuk motivsai ekstrinsik yang dapat merubah perilaku klien, dan diharapkan perilaku yang muncul akan cukup mengajarkan untuk memelihara tingkah laku yang baru.

Motivasi ekstrinsik pada penelitian ini adalah mendapatkan reward dari nilai tertinggi, tetapi karena mereka 
melaksanakan dan mereka mendapatkan manfaat yang baik dari perubahan itu, ditambah lagi mendapat respon atau pujian yang baik dari teman dan pasien, maka motivasi itu berkembang menjadi motivasi instrinsik karena responden mendapatkan langsung hadiahnya yaitu menjadi orang yang lebih baik dan direspon baik dari orang sekelilingnya. Perolehan tingkah laku yang diinginkan akhirnya dengan sendirinya akan menjadi cukup mengajarkan untuk memelihara tingkah laku yang baru yang diyakini dan dilakukannya.

\section{KESIMPULAN}

Hasil penelitian menyimpulkan bahwa rata-rata nilai kemampuan mengontrol perilaku kekerasan pada pasien rawat inap sebelum dilakukan terapi token sebesar 20,05 dan setelah dilakukan terapi token menjadi sebesar 36,02, hal ini berarti terjadi peningkatan. Berdasarkan hasil analisis statistik, maka disimpulkan bawha ada perbedaan kemampuan mengontrol kekerasan sebelum dan sesudah dilakukan terapi token $(p$ value $=$ $0,00<0,05)$. Sehingga dapat disimpulkan ada pengaruh terapi token terhadap kemampuan mengontrol perilaku kekerasan.

Berdasarkan kesimpulan penulis menyarankan agar pusat layanan pasien ekspsikotik mampu meningkatkan mutu pelayanan dengan menerapkan terapiterapi aktivitas kelompok dan psikoterapi kepada pasien gangguan jiwa secara terprogram dan terstruktur.

\section{DAFTAR PUSTAKA}

Abdul Nasir, A. M. (2011). Dasar-Dasar Keperawatan Jiwa. Jakarta: Salemba Medika.

Kemenkes RI. 2014. Riset Kesehatan Dasar (RISKESDAS) 2013. Jakarta: Balitbang Kemenkes RI.

LKS-ODK. (2016). Laporan Kesehatan Jiwa Yayasan Aulia Rahma.Rekam Medik LKS-ODK Ekspsikotik. Kemiling: $\quad$ Lampung.Tidak dipublikasikan.

Muhith, A. (2015). Pendidikan Keperawatan Jiwa. Yogyakarta: CV ANDI OFFSET.

Stuart, G. W. (2009). Buku Saku Keperawatan Jiwa . Jakarta: EGC.

Susana, S. A. (2012). Terapi Modalitas Keperawatan Kesehatan Jiwa. Jakarta: Buku Kedokteran EGC. 